e ISSN-0976-7223 | Visit Us - www.researchjournal.co.in

DOI : 10.15740/HAS/IJAE/7.2/399-401

\title{
Probability distribution functions of weekly reference crop evapotranspiration for Solapur district of Maharashtra
}

\section{A.D. BHAGAT AND M.A. PATIL}

Received : 25.04.2014; Revised : 24.08.2014; Accepted : 07.09.2014

See end of the Paper for authors' affiliation

Correspondence to :

\section{A.D. BHAGAT}

Department of Irrigation and Drainage Engineering, Mahatma Phule Krishi Vidyapeeth, Rahuri, AHMEDNAGAR (M.S.) INDIA Email : arunbhagat02@gmail.com
- ABSTRACT : The study was carried out to estimate a reference crop evapotranspiration (ETr) at different probability level for Solapur (North latitude $17^{\circ} 10^{\prime \prime}$ to $18^{\circ} 32^{\prime \prime}$ and East longitude $74^{\circ} 42^{\prime \prime}$ to $\left.76^{\circ} 15^{\prime \prime}\right)$ at $483.5 \mathrm{msl}$ in the semi-arid zone of Maharashtra. Weekly reference evapotranspiration (ETr) values for the period (1977-2007) were computed by best method Penman-Monteith FAO-56. The probability distributions that were fitted to ETr values are log normal, Gumbel and Weibulls probability distribution functions. Chi-square test was perform to know the probability distribution of best fit. ETr values at 10 per cent to 90 per cent probability level for Penman-Monteith method using probability distribution of best fit.

- KEY WORDS : Evapotranspiration, Probability distribution

ם HOW TO CITE THIS PAPER : Bhagat, A.D. and Patil, M.A. (2014). Probability distribution functions of weekly reference crop evapotranspiration for Solapur district of Maharashtra. Internat. J. Agric. Engg., 7(2) : 399401 